\title{
MODEL KAIDAH KEPUTUSAN UNTUK MENGETAHUI ELEMEN DESAIN KEMASAN PEMBENTUK PERSEPSI KONSUMEN
}

\section{MODEL DECISIONS FOR KNOWLEDGE PART DESIGN PACKAGING FORMATION OF CONSUMER PERCEPTION}

\author{
Azrifirwan $^{1)^{*}}$, Taufik Djatna ${ }^{2)}$, Syamsul Maarif ${ }^{3)}$, Mirwan Ushada ${ }^{4)}$, Endang Warsiki ${ }^{2)}$ \\ ${ }^{1)}{ }^{2)}$ Fakultas Teknologi Pertanian, Universitas Andalas, Sumatera Barat \\ Jalan Universitas Andalas, Limau Manis, Pauh, Kota Padang, Sumatera Barat, Indonesia, Kode Pos 25163 \\ Email: iwan_amir@yahoo.com \\ ${ }^{2)}$ Program Pascasarjana Teknologi Industri Pertanian, IPB \\ ${ }^{3}$ Sekolah Bisnis, Institut Pertanian Bogor, Indonesia \\ ${ }^{4)}$ Program Pascasarjana Teknologi Industri Pertanian, Universitas Gajah Mada
}

Makalah: Diterima 16 Januari 2017; Diperbaiki 2 Oktober 2017; Disetujui 20 Oktober 2017

\begin{abstract}
The packaging design elements that have appeal and take into account consumers' Kansei are crucial in introducing new products and influencing purchasing decisions. Integration of packaging design elements to produce a certain character has a combination and complexity, but can produce unequal perception. To reduce the emergence of perceptual ambiguity, then in the design process requires a measurable and standard model. The purpose of research were to design the attributes and sub elements and to make the decision rules so that the knowledge obtained underlying consumer expression. This research used a combination of Business Process Model Notation method to explain activity and data flow, Relief and Principle Component Analysis method to select design attributes and packaging selection, and Bayes Rough Set method to get the combination of decision rule. The results obtained represented the design elements and packaging samples such as size, colour, letter writing, and packaging bottle grouping as a means of reducing the number of samples. The Kansei expression of seriously was explained by a combination of text writing products that were not legibility, small font size, single color on the text, the dominant color of brown labels, black, green and no illustration of the image. The Kansei expression of eye cathing was explained by the combination of the design attributes of the sharpness of the colour, the text of the product, the text size of the product, the product text colour and the dominant colour, and the water illustration. The ergonomic aspect of bottled beverage design was that if it has a combination of highelement proportional bottles, it has a curved, low bottle cap, and a small bottle bottom diameter.
\end{abstract}

Keywords: bayes rough set, design element, decision rule, kansei

\section{ABSTRAK}

Elemen desain kemasan yang memiliki daya tarik dan memperhitungkan Kansei konsumen sangat berperan untuk memperkenalkan produk baru dan mempengaruhi keputusan membeli produk. Integrasi elemen desain kemasan menghasilkan karakter tertentu memiliki kombinasi dan kompleksitas, namun dapat menghasilkan ketidaksamaan persepsi. Untuk mereduksi munculnya ambigu persepsi, maka dalam proses desain memerlukan model yang terukur dan memiliki kebakuan metode. Tujuan penelitian adalah mendesain atribut dan sub elemen dan membuat kaidah keputusan sehingga didapatkan pengetahuan yang mendasari ekspresi konsumen. Penelitian ini menggunakan kombinasi metode Business Process Model Notation untuk menjelaskan aktivitas dan aliran data, metode Relief dan Principle Component Analysis untuk memilih atribut desain dan seleksi kemasan, serta metode Bayes Rough Set untuk mendapatkan kombinasi kaidah keputusan. Hasil penelitian didapatkan merepresentasikan elemen desain dan sampel kemasan seperti ukuran, warna, tulisan huruf, dan pengelompokan botol kemasan sebagai cara mereduksi jumlah sampel. Ekspresi kata Kansei serius dijelaskan oleh kombinasi tulisan teks produk yang tidak legibility, ukuran huruf yang kecil, warna tunggal pada teks, warna dominan label cokelat, hitam, hijau dan tidak ada ilustrasi gambar. Kata Kansei eyecathing dipersepsikan oleh kombinasi atribut desain ketajaman warna, tulisan teks produk, ukuran teks produk, warna teks produk dan warna dominan, dan ilustrasi air. Aspek ergonomis pada desain minuman kemasan botol adalah jika memiliki kombinasi elemen tinggi botol proporsional, memiliki lengkung, tutup botol rendah dan diameter dasar botol kecil.

Kata Kunci : bayes rough set, elemen desain, kaidah keputusan, kansei

\section{PENDAHULUAN}

Industri minuman ringan (ready to drink, RTD) minuman teh kemasan botol di Indonesia terus tumbuh dengan nilai mencapai Rp 40 triliun/tahun (Mardiani, 2014). Berbagai jenis minuman ringan yang permintaannya terus tumbuh adalah air mineral, minuman bersoda, teh dalam kemasan, susu 
dalam kemasan dan minuman energi (Zeffry, 2011). Pertumbuhan minuman teh akan terus naik karena memiliki market share yang lebih tinggi, disukai konsumen saat beraktivitas karena rasa, kesegaran dan praktis (Foodreview, 2016). Konsumen berusia produktif menjadi sasaran utama rodusen minuman teh, karena populasi penduduk Indonesia terbesar berada pada usia umur 20 - 29 tahun (BPS, 2013). Kelompok umur anak muda ini sangat responsif terhadap perubahan produk, suka beraktivitas dan berkumpul sambil menikmati minuman. Hal ini menjadikan elemen desain kemasan botol minuman teh memiliki daya tarik bagi konsumen melalui kombinasi antara elemen visual dan elemen struktur.

Visual elemen desain kemasan harus dapat mempengaruhi ekspektasi, persepsi dan kesukaan terhadap produk dan membantu konsumen membedakan produk, memberi perhatian khusus ketika merek tertentu berada di rak-rak penjualan (Velasco et al., 2015). Klimchuck (2012) menyebutkan ini adalah touchpoint, yaitu karakter pada elemen desain kemasan yang memudahkan konsumen untuk mengenali merek produk. Orth dan Malkowitz (2008), Gelici-Zeko et al. (2013) menyatakan masih diperlukan kajian mendalam untuk memberi panduan dalam proses desain kemasan guna memahami ekspresi-persepsi konsumen. Ekspresi konsumen dapat diungkapkan melalui kata-kata yang disebut sebagai Kansei. Kansei adalah salah satu metode pengembangan produk desain yang berorientasi kepada emosipersepsi konsumen dan menghubungkannya dengan atribut-atribut produk (Nagamachi, 2011). Integrasi dan kombinasi yang tepat pada elemen desain kemasan akan memberikan kesan positif pada konsumen, mempengaruhi perilaku untuk membeli produk (Parise dan Spence, 2012; Westerman et al., 2013; Velasco et al., 2014).

Daya tarik kemasan yang mampu mendapatkan perhatian konsumen tidak mudah untuk diformulasikan. Konsumen memiliki katakata ekspresi sendiri untuk menggambarkan preferensi mereka. Permasalahannya adalah proses desain kemasan saat ini cenderung kepada persepsi dan intuisi desainer, tidak menggunakan teknik terukur yang dapat mengetahui persepsi konsumen serta membutuhkan waktu yang lama. Data evaluasi respon konsumen terhadap elemen desain dapat menimbulkan ambiguity, vagueness ketika ada ketidaksamaan ekspresi untuk atribut keputusan pada objek desain yang sama. Ekspresi kata cantik dan tidak cantik dari konsumen untuk elemen desain yang sama akan menimbulkan ketidakpastian persepsi terhadap fitur produk. Karena itu dibutuhkan kaidah keputusan yang mampu menjawab ambiguity dan ketidakkonsistenan ekspresi pada data evaluasi.

Ekspresi yang ambigu tidak dapat ditangkap pada proses desain konvensional. Hasil diskusi dengan pakar mengungkapkan bagaimana proses desain dilakukan. Contoh kasus adalah produsen $\mathrm{X}$ akan meluncurkan produk baru $\mathrm{C}$ yang akan menjadi kompetitor produk A dan B. Desainer mendapatkan ide rancangan kemasan produk $\mathrm{C}$ dari observasi di supermarket, untuk mencari kemungkinan diferensiasi kemasan. Desainer mengambil kesatuan elemen yang mencakup warna, gambar, dan tulisan dari produk A dan mengadopsi tag line produk B dengan modifikasi pada huruf. Penjualan produk $\mathrm{C}$ berhasil memenangkan pasar karena elemen desainnya dapat mengalihkan perhatian konsumen dari produk A dan B. Penjelasan ini menunjukkan proses desain kemasan berdasarkan intuisi desainer tanpa survei konsumen dan bersifat subyektif tanpa menggunakan teknik yang mampu mengatasi kompleksitas hubungan deskripsi semantik dan deskripsi atribut pada variabel desain. Proses desain tersebut tidak dapat menangkap perbedaan ekspresi yang menimbulkan persepsi yang beragam. Hal ini sulit didapatkan pengetahuan tentang formulasi elemen-elemen desain yang akan dirancang atau melakukan inovasi.

Berdasarkan hal ini pengembangan desain kemasan membutuhkan model yang dapat mengeksplorasi kemampuan intuisi dan keahlian artistik desainer, memiliki aturan kebakuan metode yang dapat diukur. Kebakuan metode tersebut tetap harus dapat menjelaskan proses bisnis, menangkap karakteristik elemen-elemen, menstimulasi keinginan dan kebutuhan konsumen. Selain itu, metode desain berbasis persepsi harus dapat mengeksplorasi pengertian tersembunyi dari katakata konsumen, mencari relasi dan menemukan pola ekspresi konsumen dengan elemen desain yang menjadi karakter minuman teh dalam kemasan.

Salah satu metode untuk kaidah keputusan yang dapat menangkap ekspresi ambigu adalah Bayesian Roughset yang ditemukan oleh Pawlak (Zhang et al., 2012). Metode ini beranjak dari perkiraan (approximate) terhadap konsep target yang memiliki kejadian (event) dan keputusan (decision) berdasarkan kelas yang memiliki kemiripan objek berdasarkan nilai (attributte) yang sama. Konsumen dapat menyatakan objek yang sama dengan ekspresi menarik, objek lainnya tidak menarik, atau objek yang berbeda dengan ekspresi yang sama. Untuk memahami bagaimana persepsi tersebut terbentuk maka diperlukan pendekatan (approximation), yaitu pendekatan bawah (lower approximation) area ambigu apakah objek tidak masuk pada persepsi dan sebaliknya pendekatan atas (upper approximation) (Yao, 2008). Bayesian Roughset mampu mengetahui ekspresi laten Kansei konsumen dengan mengetahui region untuk menjembatani konsep approximation (Nishino et al., 2008). Tahapan penerapan metode Bayesian Roughset dapat mereduksi kata Kansei yang memiliki kelas keputusan, menentukan elemen yang berpengaruh melalui jumlah skor yang diterima pada kata Kansei, mendefinisikan atribut desain dengan tepat sehingga memiliki deskripsi yang 
cukup sehingga memudahkan perancang dapat menginterpretasikan afektif konsumen pada tahapan konsep perancangan produk (Shi et al., 2012); Yin et al. (2009); Tang et al. (2013).

Pada penelitian sebelumnya telah dilakukan identifikasi kata Kansei yang menunjukkan ekspresi konsumen, yaitu bagus, abstrak, alami, eyecathing, cerah, natural dan elegan. Kata Kansei ini dapat direpresentasikan dalam dua kata, yaitu eyecathing dan serius (Firwan et al., 2017). Dalam penelitian ini, dua kata tersebut digunakan untuk mendapatkan kombinasi elemen desain berbasis ekspresi persepsi konsumen. Tujuan penelitian ini adalah 1) mendesain atribut dan variabel desain elemen yang menentukan ekspresi konsumen, 2) membuat kaidah keputusan berdasarkan kombinasi ekspresi dan elemen desain.

\section{METODE PENELITIAN}

Metode penelitian ini dimulai dengan membuat Business Process Model Notation (BPMN). BPMN menjelaskan proses desain rekayasa Kansei berupa aliran proses aktivitas dan penyimpanan data yang melibatkan interaksi aktoraktor dan proses umpan balik informasi. Kerangka penelitian selanjutnya adalah mengidentifikasi elemen desain sampai kepada pembuatan kaidah keputusan dan membuat desain baru hasil kaidah (Gambar 1). Setiap kemasan diidentifikasi melalui diskusi pakar, studi literatur dan Focus Group Discussion sehingga diperoleh empat elemen dengan 35 sub elemen. Elemen tersebut direduksi dengan metode Relief (Kira dan Rendell, 1992) untuk mendapatkan elemen yang representatif terhadap desain kemasan botol sehingga dihasilkan tiga belas sub elemen. Sampel yang digunakan adalah 25 buah minuman teh kemasan botol dengan merek dan varian beragam. Seleksi untuk memiilih produk yang representatif menggunakan metode Principle Component Analysis (PCA) (Nagamachi, 2011). Sebanyak 20 orang responden berusia 18-25 tahun diminta menilai preferensi mereka terhadap tiga belas sub elemen tersebut dengan skala likert rentang 1-5 (tidak suka-sangat suka).

Rancangan kaidah keputusan dimulai dengan membuat tabel keputusan, yaitu kumpulan data set yang terdiri dari produk $E=\left\{E_{1}, E_{2}, \ldots, E_{j},\right\}$, atribut $A=\left\{a_{1}, a_{2}, \ldots, a_{j}\right\}$ yang terdiri dari elemen visual dan elemen struktur serta keputusan $A=$ $\left\{d_{1}, d_{2}, \ldots, d_{j}\right\}$ yang berupa ekspresi kata Kansei Serius dan Eyecathing (Nishino, 2011). Elemen visual adalah elemen yang berkaitan dengan warna, tipografi, dan gambar, sedangkan elemen struktur berkaitan dengan bentuk fisik dari kemasan. Selain memberikan penilaian terhadap elemen dan sub elemen, responden juga memberikan penilaian terhadap kemasan botol dengan merujuk kepada kata Kansei Serius atau Eyecathing dan ergonomik atau tidak ergonomik.

\section{Menghitung Nilai Kaidah Keputusan}

Tabel keputusan memiliki dua aspek peluang yaitu peluang merujuk kepada jumlah ekspresi keputusan dan atribut - sub elemen dalam satu sampel pengamatan dan peluang merujuk kepada atribut keputusan yang sama untuk keseluruhan sampel yang disebut sebagai prior probability. Hasil perhitungan peluang digunakan untuk mendapatkan information gain (Nishino, 2011).

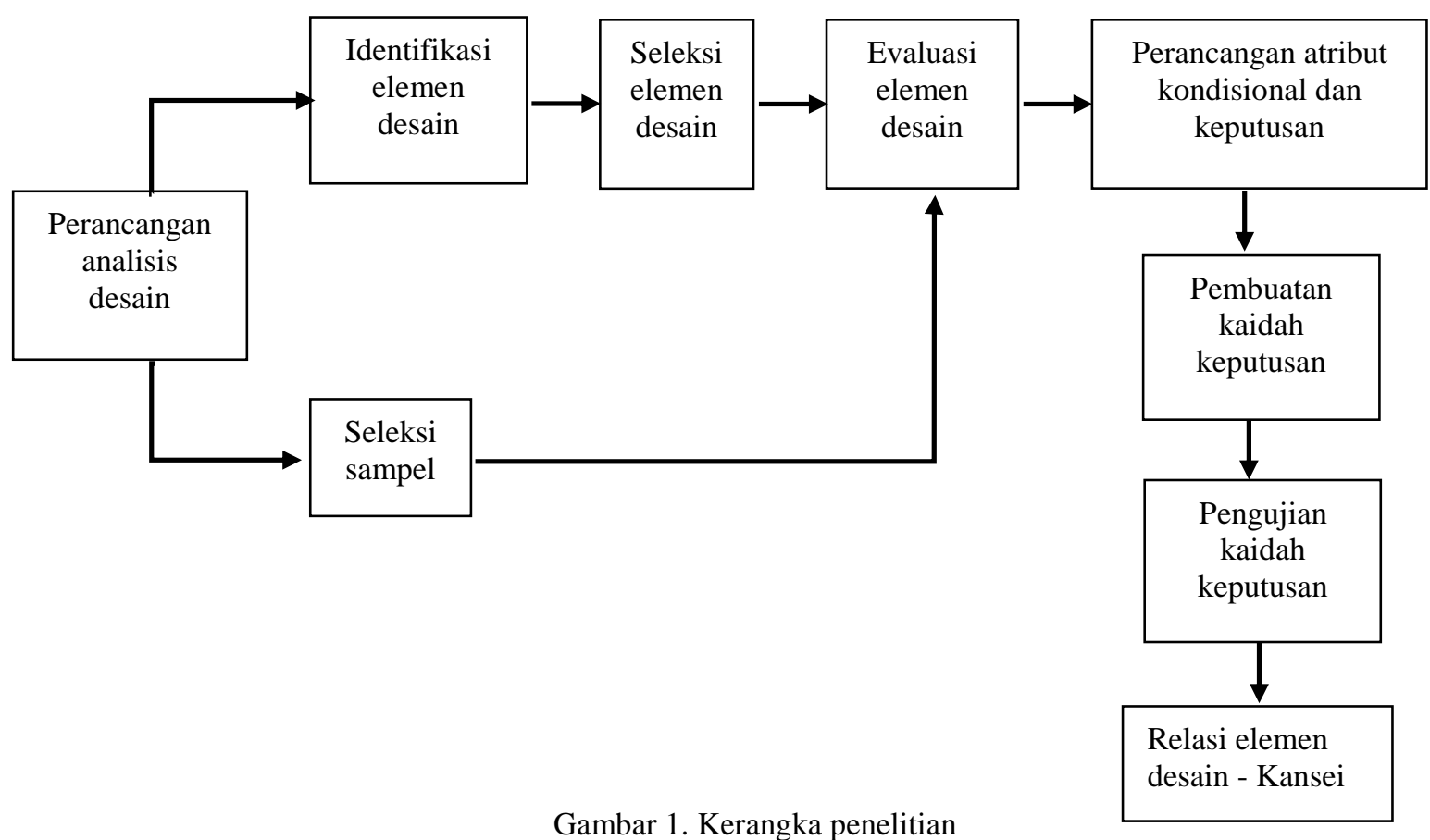


Nilai information gain digunakan untuk menentukan posisi region sebuah produk, yaitu positive, negative dan boundary region dengan persamaan 1, 2 dan 3.

positive region

$$
\operatorname{POS}^{\beta}\left(D_{j}\right)=\bigcup\left\{E_{j} \mid P\left(D_{j} \mid E_{j}\right) \geq \frac{P\left(D_{j}\right)}{1-\beta}\right\}
$$

negative region $\backslash$

$$
N E G^{\beta}\left(D_{j}\right)=\bigcup\left\{E_{j} P\left(D_{j} \mid E_{j}\right) \leq \frac{P\left(D_{j}\right)-\beta}{1-\beta}\right\}
$$

boundary region $\backslash$

$$
B N D^{\beta}\left(D_{j}\right)=\bigcup\left\{E_{j} \mid P\left(D_{j} \mid E_{j}\right) \varepsilon\left(\frac{P\left(D_{j}\right)-\beta}{1-\beta}, \frac{P\left(D_{j}\right)}{1-\beta}\right\}\right.
$$

Notasi $\beta$ dalam persamaan (1), (2), dan (3) adalah indikasi vague dalam penilaian. Semakin besar nilai $\beta$, maka tingkat keyakinan produk masuk posisi negative region dan positive region berkurang, sehingga peluang produk masuk ke dalam boundary region semakin tinggi, artinya keputusan $D_{j}$ terhadap $E_{j}$ kurang relevan, demikian sebaliknya. Nilai $\beta$ yang optimal adalah 0,2 .

Posisi region produk menjadi basis untuk membuat discernibility matrixm $x \quad n$. Discernibility matrix digunakan untuk menentukan atribut yang membawa pada keputusan. Kombinasi kaidah keputusan berasal dari fungsi (4) dan (5). Produk $E_{j}$ yang berada di positive region $\operatorname{POS}^{\beta} \quad\left(D_{j}\right)$ dibandingkan dengan produk yang berada pada negative region $N E G^{\beta}\left(D_{j}\right)$. Kombinasi elemen desain yang dipilih sebagai kaidah keputusan adalah atribut yang berbeda karakteristiknya.

$$
\begin{aligned}
& \mathrm{M}_{i j}^{\beta}\left(D_{j}\right)=\left\{\vee a_{k}=v_{i k} \mid a_{k}\left(E_{i}\right) \neq a_{k}\left(E_{j}\right) \forall a_{k} \varepsilon A\right. \\
& \operatorname{POS}^{\beta-r u l e}\left(D_{j}\right)=\vee_{E_{i} \varepsilon \operatorname{POS} \beta\left(D_{j}\right)} \wedge_{E_{j} \notin \operatorname{POS} \beta\left(D_{j}\right)} M_{i j}^{\beta}\left(D_{j}, \ldots\right.
\end{aligned}
$$

Evaluasi kekuatan kombinasi kaidah keputusan $\left(\right.$ rule $_{k}$ ) dilakukan dengan menghitung faktor certainty (6), coverage (7), dan strength (8). Certainty merupakan tingkat keyakinan keputusan yang dihasilkan untuk memprediksi evaluasi dari beragam produk elemen desain. Coverage adalah estimasi nilai atribut pada produk yang menjadi kandidat di kaidah keputusan dengan merujuk kepada kata Kansei di atribut keputusan. Strength dihitung rasio jumlah kejadian pada peluang $D_{j}$ yang dipenuhi pada $E_{j}$ dibanding dengan jumlah keseluruhan sampel.

$$
\begin{aligned}
& \operatorname{Cer}\left(\operatorname{Cond}_{k}: D_{j}=\frac{\sum E_{j} \operatorname{Cond}\left|E_{i}\right| P\left(\left(D_{j} \mid E_{i}\right)\right.}{\sum_{E i \in \operatorname{Condk}}\left|E_{j}\right|}\right. \\
& \operatorname{Cov}\left(\operatorname{Cond}_{k}: D_{j}=\frac{\sum_{E_{j} \epsilon \operatorname{Cond}_{k}}\left|E_{j}\right| \cdot P\left(D_{j} \mid E_{j}\right)}{\left|D_{j}\right|}\right.
\end{aligned}
$$

$\operatorname{Str}\left(\operatorname{Cond}_{K}: D_{j}=\frac{\sum_{E_{j} \in \operatorname{Cond}_{k}}\left|E_{j}\right| \cdot P\left(D_{j} \mid E_{j}\right)}{|E|}\right.$

Perhitungan komputasi dilakukan dengan membuat program menggunakan Java.

\section{HASIL DAN PEMBAHASAY}

Metode rekayasa Kansei hubungan respons perasaan (emosi) dengan elemen desain telah dijelaskan dengan sistematis melalui aliran proses aktivitas dan penyimpanan data ole(2) Business Process Model Notation (BPMN). BPMN juga menjelaskan interaksi aktor-aktor dan proses umpan balik informasipada desain RTD minuman teh kemasan botol. Moskowitz (2009) n(ß) nyebutkan bahwa database yang kaya informasi akan membawa kepada penemuan baru dengan pencarian relasi antar nilai atribut sehingga dapat dipelajari dinamika proses perancangan. Analisis terhadap aktor yang terlibat - stakeholder desain RTD berdasarkan kepada pendapat Klimchuk dan Krasovec (2006) yaitu departemen pemasaran, departemen rekayasa produk dan kemasan.

Berdasarkan aktor - stakeholder maka pengembangan model desain RTD memiliki beberapa tahapan. Tahapan pertama yaitu bagaimana ide dihasilkan (idea generation) melalui diskusi grup fokus (FGD) dan mengekstraksi kata yang didapatkan dari hasil diskusi. Tahapan kedua adalah pendefinisian atribut (functional dan physical definition). Pada tahap ini dilakukan diskusi dengan pakar untuk mendapatkan data-informasi elemen desain dan sub elemen desain yang menyusun RTD minuman teh kemasan botol. Tahapan ketiga adalah tahap sintesa desain aktivitas, yaitu dengan mengetahui nilai respon konsumen dan pemetaan produk berdasarkan elemen desain. Tah(4) an sintesa juga mencakupi pembuatan kaidah keputusan untuk mengetahui relasi ekspresi kata Kar 5 Sei dengan elemen desain. Tahapan terakhir adalah validasi desain, yaitu evaluasi konsep dengan membuat model desain prototipe berdasarkan pengetahuan yang didapat dari keseluruhan tahapan pengembangan model.

Analisis desain untuk kaidah keputusan yaitu aktivitas, aktor dan aliran data-informasi ditampilkan pada Gambar 2. Analisis desain terhadap desain RTD untuk mengetahui peran kebutuhan aktor yang terlibat dan kompleksitas aliran data-informasi dimana output pada satu aktivitas menjadi input bagi aktivitas berikutnya sesuai dengan pernyataan Moskowitz et al. (2009) yaitu desain kemasan merupakan kombinasi dari seni, rekayasa-engineering, ilmu konsumen dan bakat menarik perhatian. Hasil analisis desainini memberikan pengetahuan bagaimana elemen desain yang menyusun suatu produk ditetapkan dan bagaimana persepsi konsumen dapat difdentifikasi 
sesuai dengan karakteristik elemen desain penyusun RTD.

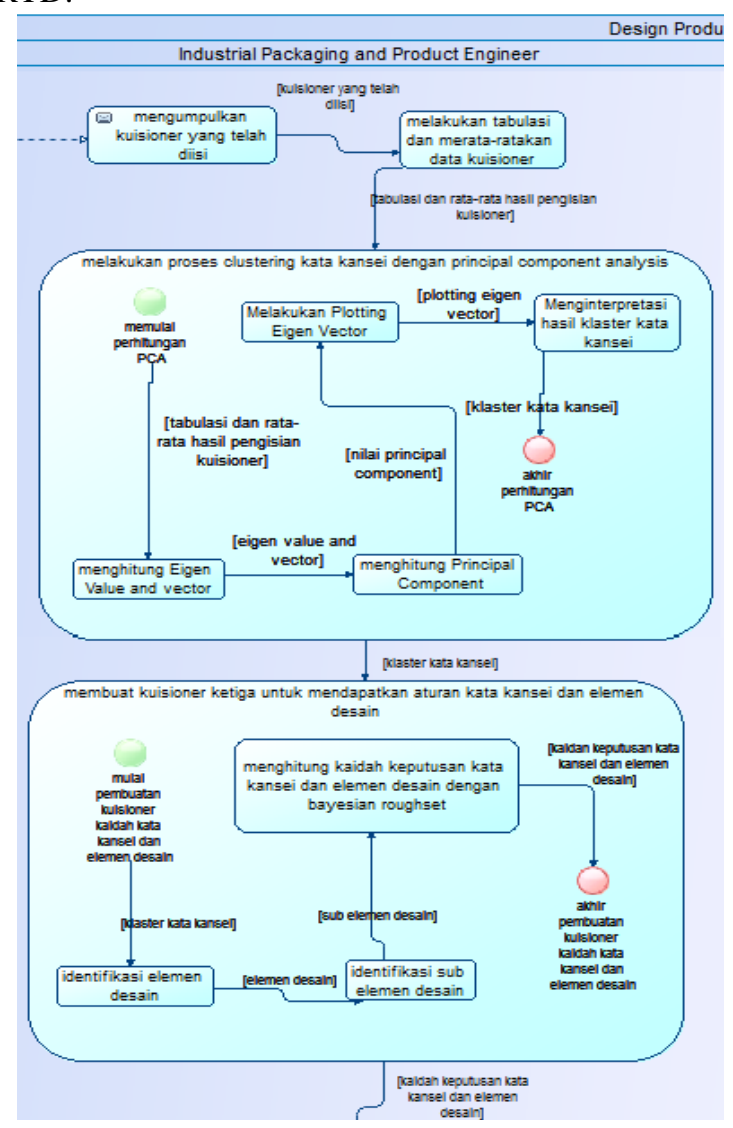

Gambar 2. Fragmen diagram BPMN reduksi

Penilaian Konsumen dan Seleksi Elemen Desain

Penilaian elemen desain oleh responden pada setiap sub elemen dan keseluruhan tampilan produk, dimana datanya digunakan untuk pembobotan Relief ditampilkan pada Tabel 1. Sub elemen tulisan teks produk penilaian tertinggi adalah 3,6 dan terendah adalah 2,9. Penilaian ini adalah menggambarkan kesukaan responden terhadap tipe huruf San Serif dan posisi huruf vertikal. Penilaian konsumen untuk sub elemen ukuran huruf teks paling tinggi yaitu 4,0 dan terendah 2,85. Esensi nilai identifikasi pada karakter desain adalah apresiasi konsumen terhadap kemasan yang memiliki karakter huruf besar, komposisi warna yang kontras serta struktur yang proporsional.

Seleksi elemen desain dengan menggunakan metode Relief, dipilih elemen yang memiliki nilai diatas ambang batas 0,9 . Sub elemen tipografi yang dipilih adalah warna, ukuran dan legibility teks. Sub elemen warna yang dipilih adalah warna keseluruhan label, warna dominan label dan ketajaman warna dengan nilai $0,177,0,154$ dan 0,153 . Sub elemen gambar yang dipilih adalah kategori gambar dan ilustrasi dengan nilai 0,149 dan 0,099. Atribut elemen struktur ada 11 sub elemen, yang memiliki nilai diatas 0,09 adalah diameter dasar, bentuk, tinggi mulut tutup, tebal botol, tinggi badan botol, dan alur. Sub elemen terpilih yang melalui keseluruhan tahapan seleksi, dipandang cukup representatif untuk mewakili kondisional atribut guna menyusun kombinasi kaidah keputusan. Seleksi minuman teh kemasan botol yang akan dipilih dengan menggunakan metode Principle Component Analysis (PCA) didapatkan 11 sampel. Proses seleksi menghasilkan pengelompokkan sampel, misal produk dengan inisial O, I dan A (Gambar 3). Kemasan botol dikelompokkan berdasarkan elemen warna dan gambar, karena memiliki kesamaan kombinasi sub elemen. Karakteristik elemen warna adalah merah, kuning, ungu, pink, cokelat, putih, hitam. Elemen gambar pada desain kemasan botol adalah daun teh, air teh, air teh dalam gelas, air/embun, kebun teh, batu es, lebah, kipas, abstrak, madu, daunan, bunga, tanaman dan ilustrasi rasa. Hasil PCA menunjukkan bahwa Produk Freshtea Green, Joytea Green dan Teh Hijau berada dalam satu kelompok, kemudian yang di pilih untuk mewakili adalah Freshtea Green. Produk Stee, Ichi Ocha Teh melati, Teh Gelas dan Liangcha berada dalam satu kelompok, karena memiliki sub elemen yang sama yaitu warna merah dan gambar. Produk Liangcha dipilih karena memiliki karakter yang dominan untuk sub elemen warna dan gambar.

Tabel 1. Hasil penilaian responden sub elemen tipografi, warna, struktur dan penilaian produk

\begin{tabular}{|c|c|c|c|c|c|c|c|c|}
\hline \multirow{3}{*}{ No } & \multirow{3}{*}{ Produk } & \multicolumn{2}{|c|}{ Tipografi } & \multicolumn{2}{|c|}{ Warna } & \multicolumn{2}{|c|}{ Struktur } & \multirow[b]{2}{*}{$\begin{array}{c}\text { Penilaian } \\
\text { keseluruhan } \\
\text { produk }\end{array}$} \\
\hline & & $\begin{array}{c}\text { Kategori } \\
\text { tulis an } \\
\text { teks } \\
\text { produk } \\
\end{array}$ & $\begin{array}{c}\text { Ukuran } \\
\text { huruf teks } \\
\text { produk }\end{array}$ & $\begin{array}{c}\text { Ketajaman } \\
\text { warna }\end{array}$ & $\begin{array}{c}\text { Warna } \\
\text { keseluruh } \\
\text { an label }\end{array}$ & $\begin{array}{c}\text { Diameter } \\
\text { das ar botol }\end{array}$ & $\begin{array}{c}\text { Volume } \\
\text { botol }\end{array}$ & \\
\hline & & $\mathbf{1}$ & 2 & 3 & 4 & 5 & 6 & 7 \\
\hline 1 & Freshtea Green & 3,6 & 3,2 & 2,6 & 2,6 & 3,1 & 4,2 & 3,4 \\
\hline 2 & Mytea & 3,6 & 4,0 & 3,9 & 4,0 & 3,4 & 4,0 & 4,2 \\
\hline 3 & Stee & 3,4 & 3,5 & 3,5 & 3,4 & 3,4 & 4,1 & 3,2 \\
\hline 4 & IchiOcha Greentea & 3,5 & 3,7 & 3,8 & 3,6 & 3,3 & 3,8 & 3,8 \\
\hline \multirow[t]{4}{*}{5} & IchiOcha Teh Melati & 3,2 & 3,5 & 3,4 & 3,2 & 2,9 & 2,9 & 2,9 \\
\hline & . & . & . & . & . & . & . & . \\
\hline & . & . & . & . & . & . & . & . \\
\hline & . & . & . & . & . & . & . & . \\
\hline 23 & WhiteTea Lechee & 3,9 & 3,8 & 3,6 & 3,9 & 3,5 & 3,7 & 3,9 \\
\hline 24 & LiangCha & 2,9 & 3,2 & 2,7 & 3,0 & 3,0 & 3,8 & 2,7 \\
\hline 25 & WhiteTea Jas mine & 3,8 & 3,8 & 3,7 & 3,8 & 3,2 & 3,4 & 4,0 \\
\hline
\end{tabular}




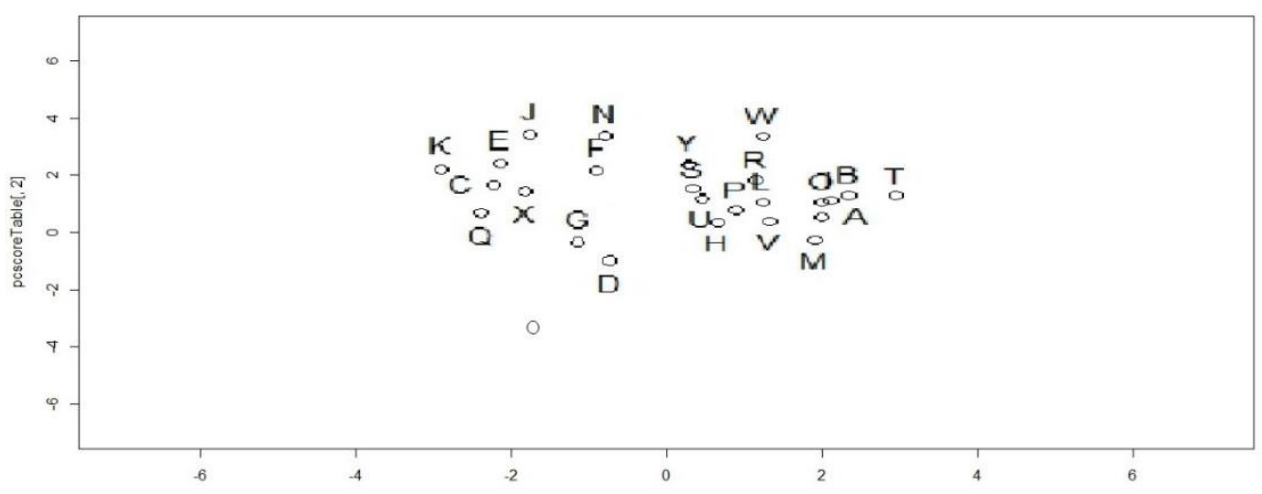

Gambar 3. Pengelompokkan kemasan botol berdasarkan warna dan gambar

\section{Kaidah Keputusan Untuk Elemen Visual}

Perancangan kombinasi elemen desain untuk menghasilkan kaidah keputusan yang dibuat dalam bentuk tabel keputusan. Karakteristik sub elemen desain dalam format tabel keputusan sebagian ditampilkan pada Tabel 2. Atribut kondisional untuk produk Freshtea Green adalah ukuran huruf adalah moderat, warna teks adalah full color, tulisan teks adalah legibility, ketajaman warna adalah moderat, warna keseluruhan label adalah menggambarkan produk, warna dominan label adalah hijau, terdapat ilustrasi alam, terdapat ilustrasi air, tidak ada ilustrasi rasa, tidak ada ilustrasi kipas, gambar tidak abstrak. Penilaian atribut ini diperoleh dengan diskusi pakar dan studi literatur.

Ekspresi atribut keputusan pada Tabel 2 terlihat perbedaan ekspresi responden untuk kemasan botol yang memiliki atribut kondisional yang sama, begitu juga terdapat ekspresi yang sama pada atribut keputusan untuk desain kemasan yang berbeda. Ekspresi responden pertama adalah serius dan responden ketujuh dan sembilan mengekspresikan sebagai Eyecathing. Untuk mengatasi ambigu deskripsi kombinasi elemen desain ini maka dimulai dengan menghitung probabilitas terhadap dua atribut. Perhitungan priorprobability atribut keputusan Serius dan Eyecathing berturut turut adalah 0,48 dan 0,52. Kata Kansei Serius dan Eyecathing memiliki nilai negative region adalah 0,36 dan 0,40 dan nilai positiveregion adalah 0,61 dan 0,64. Approximated decision classes kata Kansei Serius didapatkan produk yang masuk kategori positiveregion adalah Liangcha, Fruitea apel, Teh Botol Sosro LS, Freshtea Green, Mytea dan Teh Javana. Produk ini berada di positiveregion, karena nilai conditional probability diatas nilai prior probability yaitu 0,61. Kata Kansei Eyecathing yang memiliki nilai conditional probability diatas 0,65 masuk kepada positive region, produknya Futami, Fruit Tea Extreme, Mirai Ocha, Ichitan Teh Hijau, White Tea Jasmine.

Penentuan probabilitas dan penetapan region serta definisi kelas keputusan untuk kemasan botol RTD maka didapatkan lower atau upper approximation sebagaimana yang dinyatakan Tatsuo (2011) yaitu cara untuk mendefinisikan posisi suatu produk. Positive region adalah lower approximation dan negative region adalah upper approximatuion. Hal ini berarti produk yang berada pada satu region memiliki kesamaan (indiscernible) atribut desain dalam equivalence class dan dengan struktur discernibility matriks maka didapatkan kombinasi kaidah keputusan. Perancangan discernibility matrix yaitu baris merupakan himpunan produk yang didasarkan kepada positive region dan kolom adalah himpunan produk berdasarkan negative atau boundary region.

Kombinasi kaidah keputusan yang dihasilkan untuk kata Kansei Eyecathing dan Serius adalah 3440 dan 5877. Equivalence class juga terbentuk pada gabungan beberapa produk seperti \{Liang Cha, Fruit Tea Apel, Teh Botol Sosro LS\}, \{Liang Cha, Fruit Tea Apel\}, \{Liang Cha, Mytea, Teh Javana\}, \{Liang Cha, Teh Javana, Fruit Tea Apel\} dan \{Liang Cha, Teh Javana\} serta \{Mytea, Teh Javana\}. Equivalence class menandakan bahwa kombinasi elemen desain pada kemasan botol RTD tersebut berada dalam kelompok yang sama dan dapat dengan jelas mendefinisikan ekspresi kata Kansei Serius. Pengujian kaidah keputusan yang terbentuk dengan menghitung certainty, coverage dan strength untuk kata Kansei Seriusmenghasilkan nilai tertinggi berturut turut 0,85 dan 0,38 serta 0,18 untuk elemen desain RTD Teh Botol Sosro Less Sugar dan \{Liang Cha, Fruit Tea Apel, Teh Botol Sosro Less Sugar\}. Kaidah keputusan kata Kansei Serius ditampilkan pada Tabel 3.

Pengukuran certainty tertinggi adalah $85 \%$ yang berarti konsumen menyatakan bahwa kombinasi elemen desain kemasan memiliki ekspresi serius jika tulisan teks produk yang tidak legibility, ukuran huruf yang kecil, warna tunggal pada teks, warna dominan label cokelat, hitam, hijau dan tidak ada ilustrasi gambar. Ekspresi kata Kansei Serius untuk produk \{Liang Cha, Fruit Tea Apel, Teh Botol Sosro\} dikarakterkan oleh elemen warna yaitu ketajaman warna yang moderat dan warna tunggal pada teks. 
Tabel 2. Contoh karakteristik elemen desain dan ekspresi konsumen

\begin{tabular}{|c|c|c|c|c|c|c|c|c|c|c|c|c|}
\hline \multirow{2}{*}{$\begin{array}{c}\text { Resp } \\
\text { on } \\
\text { den }\end{array}$} & \multirow{2}{*}{$\begin{array}{c}\text { Kemasan botol } \\
\text { RTD }\end{array}$} & \multirow{2}{*}{$\begin{array}{c}\text { Ukuran huruf } \\
\text { kecil moderate besar }\end{array}$} & \multicolumn{2}{|c|}{ Warna huruf } & \multicolumn{2}{|c|}{ Tulisan huruf } & \multicolumn{3}{|c|}{ Ketajaman warna } & Gambar & \multicolumn{2}{|c|}{ Ekspresi } \\
\hline & & & $\begin{array}{c}\text { warna } \\
\text { tunggal }\end{array}$ & $\begin{array}{c}\text { full } \\
\text { color }\end{array}$ & Legibility & $\begin{array}{r}\text { Tidak } \\
\text { legible }\end{array}$ & $\begin{array}{c}\text { Tidak } \\
\text { kontras }\end{array}$ & Moderat & Kontras Abstrak & Tidak & $\begin{array}{c}\text { Eyecat } \\
\text { hing }\end{array}$ & Serius \\
\hline 1 & FreshteaGreen & $\mathrm{V}$ & & $\mathrm{V}$ & V & & & $\mathrm{V}$ & & $\mathrm{V}$ & & V \\
\hline 2 & FreshteaGreen & V & & V & V & & & V & & V & & V \\
\hline 3 & FreshteaGreen & $\mathrm{V}$ & & V & V & & & $\mathrm{V}$ & & $\mathrm{V}$ & & $\mathrm{V}$ \\
\hline 4 & FreshteaGreen & $\mathrm{V}$ & & V & V & & & V & & $\mathrm{V}$ & & V \\
\hline 5 & FreshteaGreen & V & & V & V & & & $\mathrm{V}$ & & V & & V \\
\hline 6 & FreshteaGreen & V & & V & V & & & V & & V & & V \\
\hline 7 & FreshteaGreen & $\mathrm{V}$ & & $\mathrm{V}$ & V & & & $\mathrm{V}$ & & $\mathrm{V}$ & V & \\
\hline 8 & FreshteaGreen & $\mathrm{V}$ & & V & $\mathrm{V}$ & & & V & & $\mathrm{V}$ & & V \\
\hline 9 & FreshteaGreen & $\mathrm{V}$ & & $\mathrm{V}$ & $\mathrm{V}$ & & & $\mathrm{V}$ & & $\mathrm{V}$ & $\mathrm{V}$ & \\
\hline 10 & FreshteaGreen & $\mathrm{V}$ & & $\mathrm{V}$ & $\mathrm{V}$ & & & $\mathrm{V}$ & & $\mathrm{V}$ & & $\mathrm{V}$ \\
\hline
\end{tabular}

Tabel 3. Contoh kaidah keputusan kata Kansei Serius

\begin{tabular}{|c|c|c|c|c|c|}
\hline No. & Kaidah keputusan & Cer & Cov & Str & \\
\hline 1 & $\begin{array}{l}\text { Jika Tulisan teks produk }=\text { tidak legibility \& ukuran } \\
\text { huruf teks produk }=\text { kecil \& warna teks produk }= \\
\text { warna tunggal maka Serius }\end{array}$ & 0,846 & 0,134 & 0,065 & $\begin{array}{l}\text { [Teh Botol } \\
\text { SosroLS] }\end{array}$ \\
\hline 2 & $\begin{array}{l}\text { Jika ketajaman warna }=\text { moderat } \& \text { Tulisan teks } \\
\text { produk }=\text { tidak legibility } \& \text { ukuran huruf teks produk } \\
=\text { kecil \& warna teks produk = warna tunggal maka } \\
\text { Serius }\end{array}$ & 0,846 & 0,134 & 0,065 & $\begin{array}{l}\text { [Teh Botol } \\
\text { SosroLS] }\end{array}$ \\
\hline 3 & $\begin{array}{l}\text { Jika warna dominan label = hitam \& ukuran teks } \\
\text { produk = besar maka Serius }\end{array}$ & 0,846 & 0,134 & 0,065 & [Mytea] \\
\hline 4 & $\begin{array}{l}\text { Jika ketajaman warna }=\text { kontras } \& \text { warna dominan } \\
\text { label }=\text { hitam \& ukuran teks produk = besar } \\
\text { makaSerius }\end{array}$ & 0,846 & 0,134 & 0,065 & [Mytea] \\
\hline 5 & $\begin{array}{l}\text { Jika Tulisan teks produk }=\text { tidak legibility } \& \text { ukuran } \\
\text { teks produk }=\text { moderat } \& \text { warna dominan label }= \\
\text { merah maka Serius }\end{array}$ & 0,769 & 0,244 & 0,118 & $\begin{array}{l}\text { [Liang Cha, } \\
\text { Fruit Tea } \\
\text { Apel] }\end{array}$ \\
\hline 6 & $\begin{array}{l}\text { Jika ketajaman warna }=\text { kontras \& ukuran teks } \\
\text { produk = besar \& warna dominan label = merah } \\
\text { maka Serius }\end{array}$ & 0,692 & 0,110 & 0,053 & [Teh Javana] \\
\hline
\end{tabular}

Pengetahuan yang didapatkan adalah konsumen melakukan karakterisasi atribut desain ketajaman warna dan warna tunggal sebagai ekspresi Serius. Kaidah keputusan yang memiliki nilai certainty 0,85 ini berarti nilai rasio kata Kansei Serius pada produk $\mid \mathrm{E}_{\text {Liang Cha, Fruit Tea Apel, Teh Botol Sosro }}$ P (DSerius | E Liang Cha, Fruit Tea Apel, Teh Botol Sosro) dinyatakan dengan jumlah kegiatan penilaian kemasan botol (E Liang Cha, Fruit Tea Apel, Teh Botol Sosro). Nilai certainty merupakan faktor tingkat kepercayaan (confident degree) untuk hasil prediksi konsumen (human evaluation) dari atribut desain produk.

Kaidah keputusan kata Kansei Eyecathing memiliki certainty tertinggi $92 \%$, ini menunjukkan bahwa produk yang diamati dengan kombinasi elemen desain ketajaman warna, tulisan teks produk, ukuran teks produk, warna teks produk dan warna dominan, ilustrasi air dapat mempengaruhi persepsi dan diidentifikasi konsumen. Nilai coverage tertinggi adalah $42 \%$ dimana kaidah keputusan yang merujuk kepada ekspresi Eyecathing oleh konsumen untuk keseluruhan ekspresi tersebut pada keseluruhan produk yang diamati bersifat lebih umum, yaitu karakter ketajaman warna, warna keseluruhan label yang menggambarkan produk, terdapat gambar yang mengilustrasi alam, dan warna tunggal pada teks. Penilaian certainty dan coverage terendah adalah $76 \%$ dan $11 \%$, yaitu kaidah keputusan produk disebut sebagai Eyecathing yang dihasilkan sangat spesifik, kombinasi elemen desain RTD adalah gambar elemen yang abstrak dan warna label yang ungu. Nilai strength tertinggi adalah $21 \%$, ini menjelaskan bahwa ketika ekspresi Eyecathing dibandingkan dengan keseluruhan sampel pengamatan, maka ekspresi ini kombinasi dari elemen desain ketajaman warna yang kontras, warna label menggambarkan produk. Kombinasi elemen desain ekspresi kata Kansei Eyecathing, kaidah keputusan di tampilkan pada Tabel 4. 


\section{Kaidah Keputusan untuk Elemen Struktur}

Kombinasi elemen struktur dengan ekspresi ergonomis adalah ukuran badan botol = pendek, ukuran mulut botol $=$ rendah, bodi botol= lengkung tengah, diameter dasar botol $=$ kecil. Ekspresi tidak ergonomis terkait dengan tinggi badan botol dan mulut botol serta tidak memiliki kelengkungan pada badan botol, dan aspek proporsional struktur (Tabel 5). Kombinasi elemen struktur terlihat bahwa ekspresi ergonomis konsumen berkaitan dengan aspek kenyamanan dan membuka tutup botol dan memegang kemasan. Chihara dan Yamazaki (2012) menyebutkan diameter pada tutup botol mempengaruhi respon kenyaman konsumen, Azrifirwan et al. (2017) menyatakan kenyamanan konsumen dan inovasi RTD adalah bentuk botol nyaman di genggam, bentuk botol yang unik, tutup botol yang mudah dibuka-tutup, volume dan proporsional botol. Pengetahuan terhadap kombinasi elemen struktur sangat penting dalam mendesain RTD yang dapat memberi kenyamanan bagi semua umur dan jenis kelamin.

Tabel 4. Kaidah keputusan kata Kansei Eyecathing

\begin{tabular}{|c|c|c|c|c|c|}
\hline No & Rules & Cer & Cov & Str & Produk \\
\hline 1 & $\begin{array}{l}\text { Jika ketajaman warna }=\text { kontras } \& \text { teks produk }= \\
\text { legibility } \& \text { ukuran huruf teks produk }=\text { moderat } \& \\
\text { warna teks produk }=\text { warna tunggal } \& \text { warna } \\
\text { dominan label = cokelat maka Eyecathing }\end{array}$ & 0,923 & 0,138 & 0,071 & [Mirai Ocha] \\
\hline 2 & $\begin{array}{l}\text { Jika ketajaman warna }=\text { kontras } \& \text { teks produk }= \\
\text { legibility } \& \text { ukuran huruf teks produk }=\text { moderat } \& \\
\text { warna teks produk }=\text { warna tunggal } \& \text { ilustrasi rasa } \\
=\text { tidak ada maka Eyecathing }\end{array}$ & 0,923 & 0,138 & 0,071 & [Mirai Ocha] \\
\hline 3 & $\begin{array}{l}\text { Jika ketajaman warna }=\text { kontras } \& \text { warna } \\
\text { keseluruhan label = menggambarkan produk \& } \\
\text { warna teks produk = warna tunggal \& ilustrasi rasa } \\
=\text { tidak ada \& ilustrasi air = ada maka Eyecathing }\end{array}$ & 0,923 & 0,276 & 0,142 & $\begin{array}{l}\text { [White Tea } \\
\text { Jasmine, Mirai } \\
\text { Ocha] }\end{array}$ \\
\hline 4 & $\begin{array}{l}\text { Jika ukuran huruf teks produk }=\text { kecil \& warna } \\
\text { teks produk }=\text { full color maka Eyecathing }\end{array}$ & 0,923 & 0,138 & 0,071 & [Ichitan Teh Hijau] \\
\hline 5 & $\begin{array}{l}\text { Jika ketajaman warna }=\text { kontras } \& \text { warna } \\
\text { keseluruhan label }=\text { menggambarkan produk } \& \\
\text { tulisan teks produk = tidak legibility maka } \\
\text { Eyecathing }\end{array}$ & 0,923 & 0,276 & 0,142 & $\begin{array}{l}\text { [Ichitan Teh Hijau, } \\
\text { White Tea Jasmine] }\end{array}$ \\
\hline
\end{tabular}

Tabel 5. Kaidah keputusan struktur elemen desain

\begin{tabular}{|c|c|c|c|c|}
\hline Kaidah Keputusan & Cer & Cov & Str & Produk \\
\hline $\begin{array}{l}\text { Jika ukuran badan botol=pendek \& ukuran mulut botol = rendah } \& \\
\text { bodi botol = lengkung tengah Ergonomis }\end{array}$ & 0,769 & 0,110 & 0,059 & [Teh Javana] \\
\hline $\begin{array}{l}\text { Jika ukuran badan botol=pendek \& ukuran mulut botol = rendah \& } \\
\text { bodi botol = lengkung tengah \& diameter dasar botol = kecil } \\
\text { Ergonomis }\end{array}$ & 0,769 & 0,110 & 0,059 & [Teh Javana] \\
\hline $\begin{array}{l}\text { Jika ukuran badan botol=pendek \& bodi botol = lengkung tengah } \\
\text { Ergonomis }\end{array}$ & 0,769 & 0,110 & 0,059 & [Teh Javana] \\
\hline $\begin{array}{l}\text { Jika ukuran badan botol=pendek \& bodi botol = lengkung tengah } \\
\& \text { diameter dasar botol }=\text { kecil Ergonomis }\end{array}$ & 0,769 & 0,110 & 0,059 & [Teh Javana] \\
\hline $\begin{array}{l}\text { Jika ukuran badan botol=pendek \& ukuran mulut botol = rendah } \\
\text { Ergonomis }\end{array}$ & 0,769 & 0,110 & 0,059 & [Teh Javana] \\
\hline $\begin{array}{l}\text { Jika ukuran badan botol=pendek } \& \text { ukuran mulut botol }=\text { rendah } \& \\
\text { diameter dasar botol = kecil Ergonomis }\end{array}$ & 0,769 & 0,110 & 0,059 & [Teh Javana] \\
\hline $\begin{array}{l}\text { Jika ukuran badan botol=pendek \& diameter dasar botol = kecil } \\
\text { Ergonomis }\end{array}$ & 0,769 & 0,110 & 0,059 & [Teh Javana] \\
\hline $\begin{array}{l}\text { Jika ukuran mulut botol = rendah \& ukuran badan botol = tinggi \& } \\
\text { diameter dasar botol = kecil maka tidak ergonomis }\end{array}$ & 0,923 & 0,154 & 0,071 & [Liang Cha] \\
\hline $\begin{array}{l}\text { Jika ukuran badan botol = tinggi \& ukuran mulut botol = rendah } \& \\
\text { diameter dasar botol = kecil maka tidak ergonomis }\end{array}$ & 0,923 & 0,154 & 0,071 & [Liang Cha] \\
\hline Jika bodi botol $=$ tidak lengkung tengah maka tidak ergonomis & 0,615 & 0,103 & 0,047 & [Futami 17 GT] \\
\hline $\begin{array}{l}\text { Jika bodi botol = tidak lengkung tengah } \& \text { ukuran mulut botol = } \\
\text { tinggi maka tidak ergonomis }\end{array}$ & 0,615 & 0,103 & 0,047 & [Futami 17 GT] \\
\hline
\end{tabular}




\section{KESIMPULAN DAN SARAN}

\section{Kesimpulan}

Pembuatan model telah dapat mereduksi jumlah elemen-sub elemen dan sampel kemasan untuk mendapatkan data yang representatif dan menghasilkan kaidah keputusan. Penerapan metode Relief pada elemen desain - sub elemen terpilih adalah tipografi \{warna teks produk, ukuran huruf dan legibility teks produk\}, warna \{warna keseluruhan label, warna dominan label dan ketajaman warna \} dan gambar \{kategori gambar dan ilustrasi\} dan struktur \{bentuk alur, bentuk lengkung, tutup botol, tebal botol, tinggi dan diameter dasar botol\}. Penggunaan metode PCA telah menyeleksi jumlah sampelmenjadi 11 buahberdasarkan elemen warna dan gambar. Penggunaan metode tersebut telah mempermudah proses komputasi pada kaidah keputusan.

Kaidah keputusan yang dibuat dengan metode Bayesian Rough Set telah menghasilkan kombinasi elemen dan sub elemen untuk menghasilkan ekspresi kata Kansei Serius dan Eyecathing. Ekspresi sebuah produk disebut Serius dikarakterkan oleh kombinasi tulisan teks produk yang tidak legibility, ukuran huruf yang kecil, warna tunggal pada teks, warna dominan label cokelat, hitam, hijau dan tidak ada ilustrasi gambar. Nilai certainty, coverage dan strength untuk ini adalah berturut turut adalah 0,85, 0,4 dan 0,21. Kata Kansei Eyecathing dipersepsikan oleh kombinasi atribut desain ketajaman warna, tulisan teks produk, ukuran teks produk, warna teks produk dan warna label dominan adalah cokelat, merah, hijau, putih, dan terdapat ilustrasi air. Nilai certainty, coverage dan strength untuk ini adalah berturut turut adalah 0,77, 0,12 dan 0,06. Ekspresi kemasan botol ergonomis adalah memiliki elemen struktur seperti tinggi botol, lengkung, tutup botol dan diameter dasar botol. Nilai certainty, coverage dan strength untuk ini adalah berturut turut adalah 0,6,0,1 dan 0,05.

\section{Saran}

Memberi definisi sub elemen desain mempertimbangkan penggunaan nama yang relevan sehingga komposisi kaidah keputusan lebih representatif. Pengujian dengan menggunakan metoda lainnya seperti fuzzy roughest dan membuat desain kemasan baru berdasarkan kombinasi elemensub elemen hasil pengetahuan kaidah keputusan.

\section{DAFTAR PUSTAKA}

[BPS] Badan Pusat Statistik. 2013. Proyeksi Penduduk Indonesia 2010 - 2035. Jakarta.

Azrifirwan. 2017. Pengembangan model desain kemasan minuman ringan berbasis Kansei Enginering. [Disertasi]. Bogor. Institut Pertanian Bogor.
Calver G. 2004. What Is Packaging Design? Hove (UK): Roto Vision SA.

Chihara T dan Yamazaki K. 2012. Evaluation function of drinking ease from aluminum beverage bottles relative to optimum bottle opening diameter and beverage type. Appl Ergon. 43(1): 157-165.

Gelici-Zeko MM, Lutters D, ten Klooster R, Weijzen PLG. 2013. Studying the influence of packaging design on consumer perceptions (of dairy products) using categorizing and perceptual mapping. Packaging Technology and Science. 26 (4):215-228.

Jedlicka W. 2009. Packaging Sustainability: Tools, Systems and Strategies for Innovative Package Design. New Jersey (USA): John Wiley \& Sons, Inc.

Kira K dan Rendell LA. 1992. The feature selection problem : Traditional methods and a new algorthim. AAAI Proceedings.

Klimchuck MR dan Krasovec SA. 2012. Packaging Design: Successful Product Branding From Concept To Shelf. Edisi Ke-2. New Jersey (USA): John Wiley and Sons, Inc.

Mardiani D. 2014. Industri Gemari Pasar Indonesia untuk Minuman Kemasan Harian Republika. 5 Februari 2014.

Moskowitz HR, Reisner M, Kawlor Jb, Deliza R. 2009. Packaging Research In Food Product Design and Development. Wiley-Blackwell.

Nagamachi M. 2011. Kansei/Affective Engineering. New York (USA): CRC Press.

Nishino T, Nagamachi M, dan Tanaka H 2005. Variable precision bayesian rough set model and its application to human evaluation data. Di dalam: Slezak D, Wang G, Szczuka, Duntsch I, Yao Y, editor. RSFDGrC. Berlin (GER): Springer.

Nishino T, Satsuta R, dan Nagamachi M. 2008. Identification of customers' latent Kansei needs and product design by rough set based approach. 11th QMOD Conference. Helsinborg, Swedia.

Orth UR dan Malkowitz K. 2008. Holistic package design and consumer brand impressions. Journal of Marketing. 72(3):64-81.

Parise CV dan Spence C. 2012. Assessing the assosiations between brand packaging an brand attributes using an indirect performance measure. Journal Food Quality and Preference. 24:17-23.

Shi F, Sun S, dan Xu J. 2012. Employing rough sets and association rule mining in Kansei knowledge extraction. Information Sciences. 196:118-128.

Tang CY, Fung KY, Lee EWM, Ho GTS, Siu KWM, Mou WL. 2013. Product form design using customer perception evaluation by a combined superellipse 
fitting and ANN approach. Advanced Engineering Informatics. 27 (3):386-394.

Tatsuo N. 2011. Rough Set Theory and Kansei Affective Engineering. New Jersey (USA): CRC Press.

Velasco C, Woods AT, dan Spence C. 2015. Evaluating the orientation of design elements in product packaging using an online orientation task. Food Quality and Preference. 46: 151-159.

Westerman SJ. 2013. The design of consumer packaging: effects of manipulations of shape, orientation, and alignment of graphical forms on consumers' assessments. Food Quality and Preference. 27 (1): 8-17.
Yao Y. 2008. Probabilistic rough set approximations. International Journal of Approximate Reasoning. 49: 255 - 271.

Yin ZL, Pheng KL, dan Wei ZZ. 2009. A dominance-based rough set approach to Kansei engineering in product development. Expert System With Application. 36:393-402.

Zeffry A. 2011. Analisis faktor faktor yang mempengaruhi pemilihan jenis minuman ringan dan implikasinya terhadap strategi pemasaran. [Tesis]. Bogor: Institut Pertanian Bogor.

Zhang X, Mo Z, Xiong F, Cheng W. 2012. Comparative study of variabel precision rough set model and graded rough set model. International Journal of Approximate Reasoning. 3: 104 - 116. 